\title{
LÉZERSUGÁRRAL FELÜLETKEZELT ACÉL MINTÁK BALL-ON-DISK TÍPUSÚ KOPTATÓ VIZSGÁLATA
}

\author{
Dr. MARKOVITS TAMÁs, egyetemi docens \\ BME Közlekedésmérnöki és Jármümérnöki Kar, Gépjármütechnológia Tanszék \\ Dr. Borbás LaJos, Professor Emeritus \\ EDUTUS Egyetem, Müszaki Intézet \\ borbas.lajos@edutus.hu \\ MoLNÁr LÁSZLó, m. tanár, \\ EDUTUS Egyetem, Müszaki Intézet \\ molnar.laszlo@edutus.hu \\ NAGY ANDRÁS LAJOS, FülöP DÁvid, \\ Széchenyi István Egyetem, \\ Belső Égésű Motorok és Járműhajtások Tanszék
}

DOI 10.47273/AP.2020.20.51-63

\begin{abstract}
ABSZTRAKT
A bemutatott kutatásban lézersugárral felületkezelt acél minták ball-on-disk típusú koptató vizsgálatának eredményeit mutatjuk be. A lézeres felületkezeléssel létrehozott edzett és nikkel bázisú wolfram karbid tartalmú bevonatolt tárcsák koptató vizsgálatait végeztük el, azzal a céllal, hogy meghatározzuk a kopással szembeni ellenállás változását a kezeletlen acél alapanyagokhoz képest. A kapott eredményekböl jól látható, hogy a lézerrel felületkezelt alapanyagok kopásállósága jobb volt, mint felületkezelés nélkül. Az eredményekben bemutatásra kerülnek jellegzetes kopási nyomok, kopási szélességek, mélységek, keresztmetszetek, a lekoptatott tömeg és a súrlódási együttható változása a különböző esetekben.
\end{abstract}

Kulcsszavak: lézersugaras megmunkálás, kopás, pin-on-disc vizsgálat

\begin{abstract}
In case of laser surface treatments it is necessary to determine the main technological parameters, taking into account the possibilities and limitations of the applied system elements. In the present research the results of different technological parameters influenced by the surface properties measured by ball-on-disc veering measurement have been introduced.
\end{abstract}

Keywords: laser beam technologies, wear, pin-on-disc measurement 


\section{BEVEZETÉS}

Az alkatrészek felületi tulajdonságainak változtatására sok eljárás létezik. Ezek közül egyik elterjedt és precízen megvalósítható módszer, ha lézersugár segítségével változtatjuk meg a felületi tulajdonságokat. Az egyik gyakori követelmény a felületi tulajdonságokkal szemben a felületek keménységének és kopásállóságának növelése, amire többféle lézeres eljárás létezik. A kutatás korábbi fázisában a lézersugaras edzés és lézersugaras bevonatolás technológiáját dolgoztuk ki acél próbatestekre. Ebben a közleményben a létrehozott próbatestek koptatási vizsgálatait, és azok eredményeit mutatjuk be [1,2].

Különféle kísérleti elrendezések és vizsgálati eljárások állnak rendelkezésre a müszaki felületek kopással szembeni ellenálló képességének meghatározására. A kopási folyamatra számos tényező van hatással, amelyek megváltoztatása a kopásfolyamatok jellegét nagymértékben befolyásolja. A koptatási kísérlet során a kapcsolódó felületek által kialakított érintkezés lehet pontszerü, vonalmenti vagy felületi. A kopásfolyamatokat befolyásoló jellemzők között megtalálhatók az alaptest és ellentest anyaga, az érintkező felületek geometriája és felületi jellemzői, az alkalmazott közbenső anyag, illetve a környezeti közeg. Fontos folyamatparaméter az érintkező felületeket terhelő normálerő, a felületek egymáshoz viszonyított sebessége, az érintkező felületek hőmérséklete és a vizsgálat időtartama. Fontos továbbá a felületek mozgásviszonya (egyenes, forgó, spirál), a kenőanyag típusa (szilárd / folyékony kenőanyaggal vagy kenőanyag nélkül), valamint a testek, a kenőanyag és a környezet hőmérséklete $[3,4]$.

A vizsgálat kimeneteként a lekopott geometria jellemzői (szélesség, mélység és keresztmetszet), illetve a lekoptatott tömeg és a súrlódási állapotot jellemző mennyiségek (súrlódási erő, súrlódási együttható) adhatók meg.

A jelen publikációban bemutatott vizsgálat célja a lézerrel felületkezelt és a nem felületkezelt minták ugyanolyan terhelési állapotban, azonos körülmények között történő összehasonlítása. A vizsgálatok során a kezelt minták kezeletlen alapanyagokhoz képesti kopási ellenállás változását ball-on-disk típusú koptatógépen határoztuk meg.

\section{AZ ELVÉGZETT VIZSGÁLATOK}

A kezeletlen, edzett és a bevonatolt minták koptatási vizsgálatát egy IAVF gyártmányú tribométeren (1. ábra) végeztük el. 
Az alkalmazott berendezésbe illeszkedő vizsgálati minták makrogeometriája tárcsa alakú, geometriai méretei a 2. ábrán láthatóak. A hengeres tárcsák fedőlap felülete volt felületkezelve. A kísérletek során használt hengeres tárcsa vastagsága 5,2 mm, átmérője $37 \mathrm{~mm}$, a közepén található furat átmérője $9 \mathrm{~mm}$. A tárcsák kezelt felületi érdességét a kísérletek során meghatároztuk.

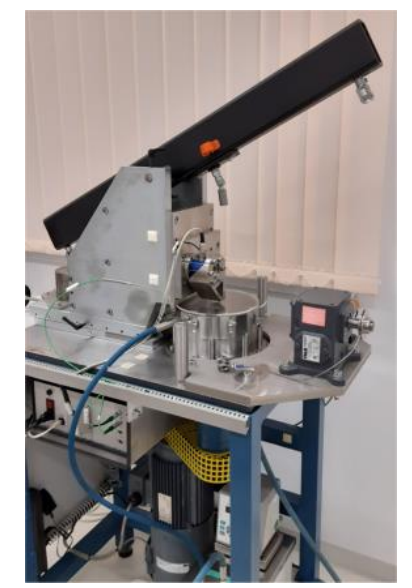

1. ábra. Az alkalmazott koptató berendezés

Az ellendarab egy 6 mm átmérőjü, 100Cr6 anyagú edzett acél golyó volt. A koptatási tesztek kenőanyag adagolás nélkül (szárazon) történtek, $60 \mathrm{~N}$ normálerővel és $0,075 \mathrm{~m} / \mathrm{s}$ kerületei sebességgel. Az edzett daraboknál a tárcsa anyaga C45-ös acél volt, a bevonatolt darabok esetében M-1001WC-PL2 típusú nikkel bázisú WC porból készült réteget vittünk fel az S235ös acél alaplemezre.

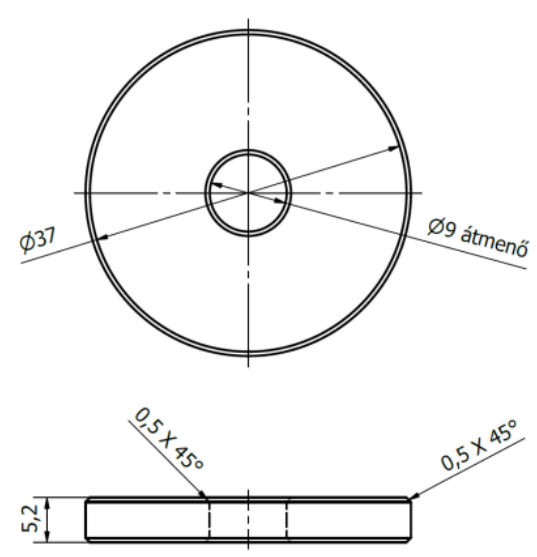

2. ábra. A koptatási vizsgálat próbatest geometriája

Az elvégzett vizsgálatok után meghatároztuk a kopás mélységét, a kopás szélességét, a kopott keresztmetszetet, valamint a lekopott tömeg mennyiségét. A súrlódási együtthatót a vizsgálatok teljes időtartama alatt rögzítettük. 
A felületkezelt mintákon egy-egy körpálya mentén végeztük a koptatást 12 mm-es sugáron. Az alapanyagok esetében egy mintán három pálya mentén azonos koptatási sebesség mellett végeztünk vizsgálatokat, mivel itt a réteg inhomogenitásának lehetőségével nem kellett számolni. A beállításról készült fotókat koptatás előtti és utáni helyzetről a 3. ábrán láthatjuk.

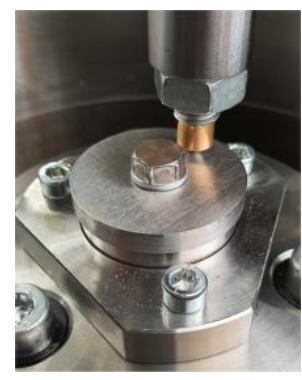

(a)

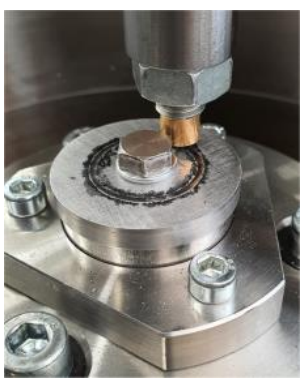

(b)

3. ábra. A koptató vizsgálat elötti (a) és utáni (b) állapotról készült felvételek

A koptatási vizsgálatok során a minták jelölését, az alapanyagokat, a rétegeket, a minták darabszámát és a réteg előállítás stratégiáját az 1. táblázatban foglaltuk össze.

A lézeres edzésnél és a bevonatolásnál is egymással párhuzamos sávokat hoztunk létre, amelyeket a koptatás előtt köszörüléssel munkáltunk ki. Az edzett daraboknál kialakítottunk 12 mm-es sugáron, körpálya mentén megvalósítandó edzési stratégiát is, amivel a sávok közötti kilágyulás hatását ki tudtuk küszöbölni.

\begin{tabular}{|l|c|c|c|c|}
\hline Minta jelölése & alapanyag & réteg & $\begin{array}{c}\text { Minta } \\
\text { darabszáma } \\
(\mathrm{db})\end{array}$ & $\begin{array}{c}\text { Réteg előállitási } \\
\text { stratégia }\end{array}$ \\
\hline EK1, EK2, EK3 & C45 acél & Edzett & 3 & Körpálya mentén \\
\hline ES1, ES2, ES3 & C45 acél & Edzett & 3 & Sávosan átlapolással \\
\hline C45 & C45 acél & - & 1 & - \\
\hline EP1, EP2, EP3 & S235 acél & bevonatolt & 3 & Sávosan átlapolással \\
\hline S235 & S235 acél & & 1 & - \\
\hline
\end{tabular}

1. táblázat. A koptatásnál használt minták jelölési rendszere 


\section{EREDMÉNYEK BEMUTATÁSA}

A koptatási vizsgálatok során kapott eredményeket a továbbiakban együtt mutatjuk be a lézersugaras edzés és a bevonatolás során kapott eredményekkel.

A kopási nyomok közül a lézeres mozgatás stratégiájától való függés illusztrálását mutatjuk be az edzett és a C45-ös alapanyag felületén. A 4. ábrán az EK jelü kör mentén edzett minták kopási nyomai figyelhetőek meg. A körpályán történő edzésnél a lézersugár és a koptató ellendarab is a 12 mm-es rádiusznál haladt, így a legnagyobb keménységű helyen történt a koptatás megvalósítása. Az ábrán megfigyelhető, hogy a kerület mentén a kopási nyomban nagy eltérés makro szinten nem tapasztalhatók.
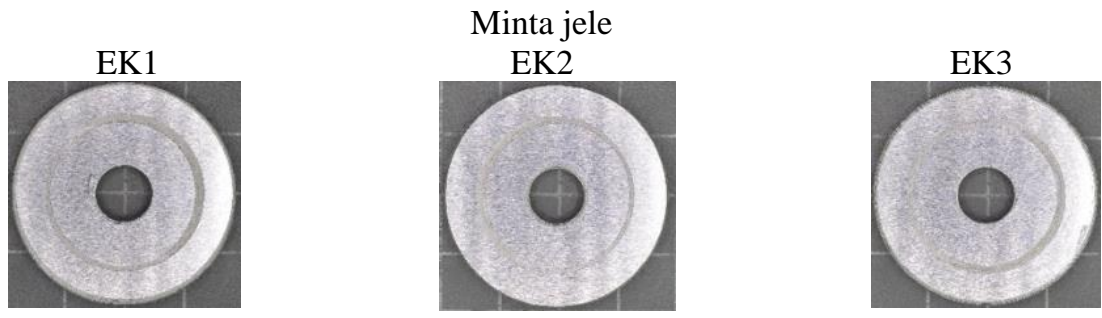

4. ábra. A koptatott tárcsák fotói az EK jelü mintáknál

Az 5. ábrán a sávosan hőkezelt minták kopási nyomainak makrofotói láthatóak. Az előző mintához képest itt már láthatóak a kerület mentén eltérések a kopási nyom szélességében, ami a sávos hőkezelési stratégia jellemzőiből fakad, ahogy erre számítani is lehetett. A sávok elhelyezkedésétől függően a keményebb részeken keskenyebb, míg a kilágyult részeken már szabad szemmel is szélesebb kopásnyom figyelhető meg.

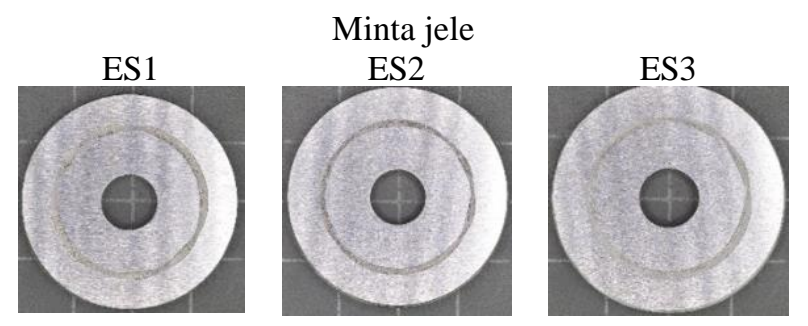

5. ábra. A koptatott tárcsák fotói az ES jelü mintáknál

A 6. ábrán a C45-ös alapanyagból készített minta kopásnyomának fotóit mutatjuk be. Itt az alapanyagon 3 különböző átmérőn végeztünk koptatást a mérés bizonytalanságának bemutatása érdekében. Mivel az alapanyag nem kapott semmilyen hőkezelést, ezért a mintában nem volt inhomogenitás, ami a mérést zavarta volna. 


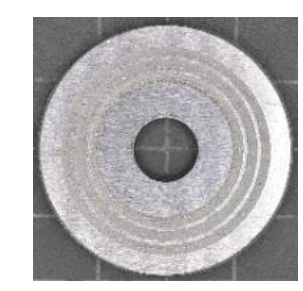

6. ábra. A koptatott tárcsa fotója a C45 jelü mintánál

A bevonatolt daraboknál a p jelü minták kopási mikro felvételei alapján a kopási nyomon megfigyelhető, hogy kevésbé éles annak kontúrja, mint az edzett daraboknál, valamint a kerület menti eloszlása is egyenletesebb. A darabok között nem látható jelentősebb eltérés és periodicitásra utaló jelet sem tapasztaltunk.

A kopási nyom szélességeket mikroszkópon mértük, a kapott eredményeket a 7. ábrán mutatjuk be.

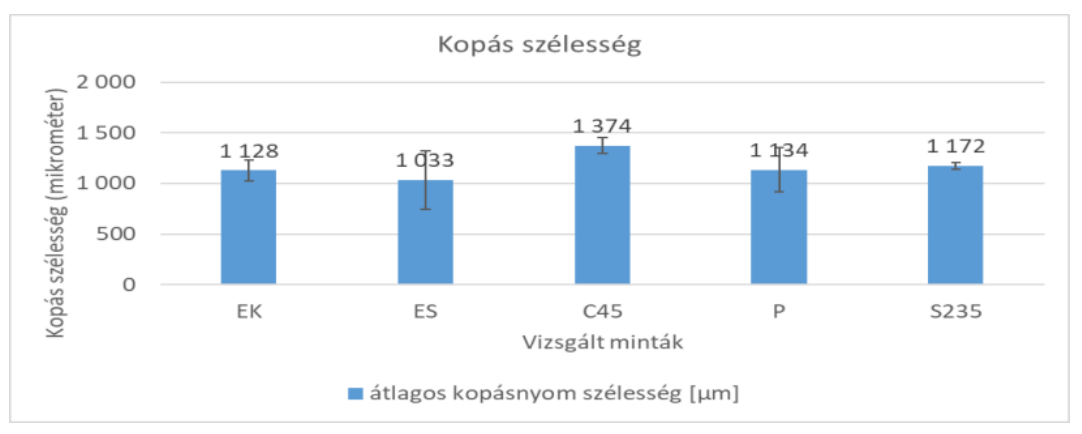

7. ábra. A kopási szélesség értéke a különbözö jelü mintáknál

A kopási nyom szélessége $1 \mathrm{~mm}$ feletti értéket adott minden mintánál. Az edzett daraboknál jól látható, hogy a C45-ös alapanyaghoz képest az EK és az ES mintáknál is kisebb szélesség adódott. A sávos hőkezeléssel gyártott minták esetében ez még valamelyest kisebb (25\%-os csökkenés), mint a körpálya mentén edzett daraboké (18 \%-os csökkenés), ami meglepő eredmény a korábbi várakozásainkkal szemben. Mint az már korábban is említettük, a felülnézetben látható kopási szélesség önmagában nem jellemzi megfelelő módon a kopással szembeni ellenállást.

Az S235-ös alapanyaghoz képest a bevonatolt darab kopásnyomának szélessége kisebb lett átlagosan $4 \%$-kal, ami nem tekinthető túlzottan nagy eltérésnek. Az is megállapíthatjuk, hogy a bevonatolt darab mérési eredményeinek a szórása többszöröse az alapanyag esetén mért értékeknek, ami a bemutatott felvételeinken is látható volt.

A kopási nyom szélességén kívül további fontos jellemző a kopás mélységének értéke is. Ennek mértékét a félkörhöz hasonló geometriájú kopási nyom alsó pontjának és a felületnek a 
távolságaként határoztuk meg. A mért értékek -hasonlóan, ahogyan a szélességi értékeket bemutattuk - a 8. ábrán közölt diagramban mutatjuk be.

Az eltérések jellege és iránya a korábban bemutatottakhoz hasonló sajátosságokat követ, azonban az jellemzők mértékében jelentős eltérést figyelhetünk meg.

Az edzett darabok esetén a kopási mélység átlagosan a körpálya mentén edzett EK daraboknál volt a legkisebb, itt a csökkenés 40 \% valamint az ES jelölésű daraboknál is nagyobb csökkenés volt tapasztalható (30\%) az C45-ös alapanyagok mért értékeihez viszonyítva. Az ES jelü daraboknál a felvételeken látható kopási nyom egyenetlenségek mélység irányban is megjelentek, így az ES jelü minták mérési eredményei mutatták a legnagyobb szórási értékeket. További eredmény, hogy a C45-ös minták esetén a mérési eredmények szórási értékei a szélességi méreteknél is nagyobb értékeket mutattak.

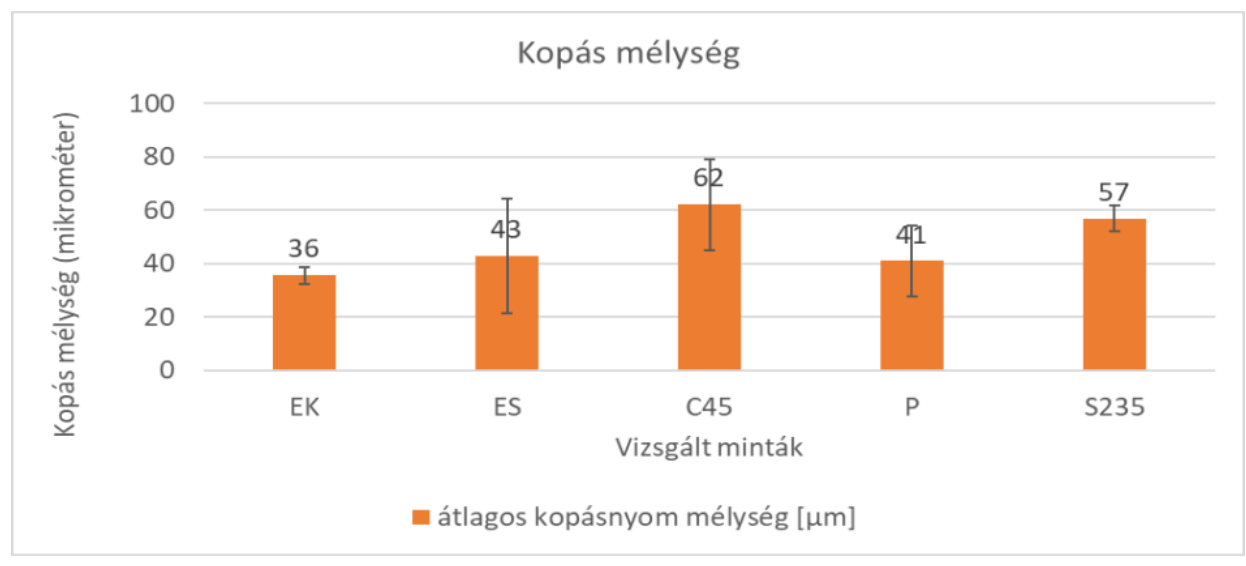

8. ábra. A kopási mélység értéke a különbözö jelü mintáknál

A bevonatolt mintáknál a korábbi diagramon a szélességben nem volt nagy eltérés, azonban a mélységben a csökkenés már jelentősebb, 38 \% mértékü, ami arra utal, hogy a nikkel bázisú bevonat mélység irányú kopásállósága nagyobb a bevonatolás nélküliekhez viszonytva.

A kopási nyom szélessége és mélysége jellemzi a kopási tulajdonságokat, azonban a mért kopási keresztmetszet már figyelembe veszi a kopásnyom ideálisnak feltételezett félkörívtől való eltéréseit is. Ezért a következőkben a kopási keresztmetszet jellemző alakjának alakulását mutatjuk be .

A 9. ábrán a $\mathrm{P}$ bevonatolt minta kopásnyomának keresztmetszeti kontúrja látható. A korábbiakhoz képest itt a félkör alaknál jóval laposabb kontúr alakul ki. Itt nem félkör alakú a kontúr, hanem egy aszimmetrikus laposabb formához hasonlít. A szélesség mélység arány itt a legnagyobb. 


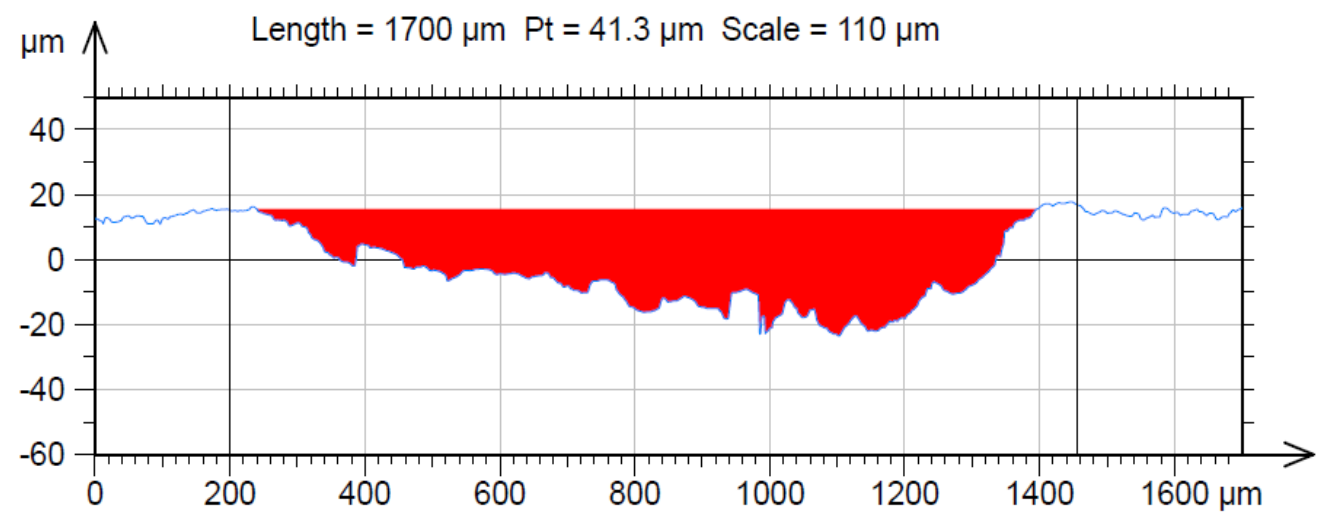

9. ábra. Jellemzö EP minta kopási keresztmetszete

A 10. ábrán az S235-ös acéllemez minta kopási nyoma látható. Itt is láthatóak kisebb, nagyobb kopási egyenetlenségek a keresztmetszeti kontúron.

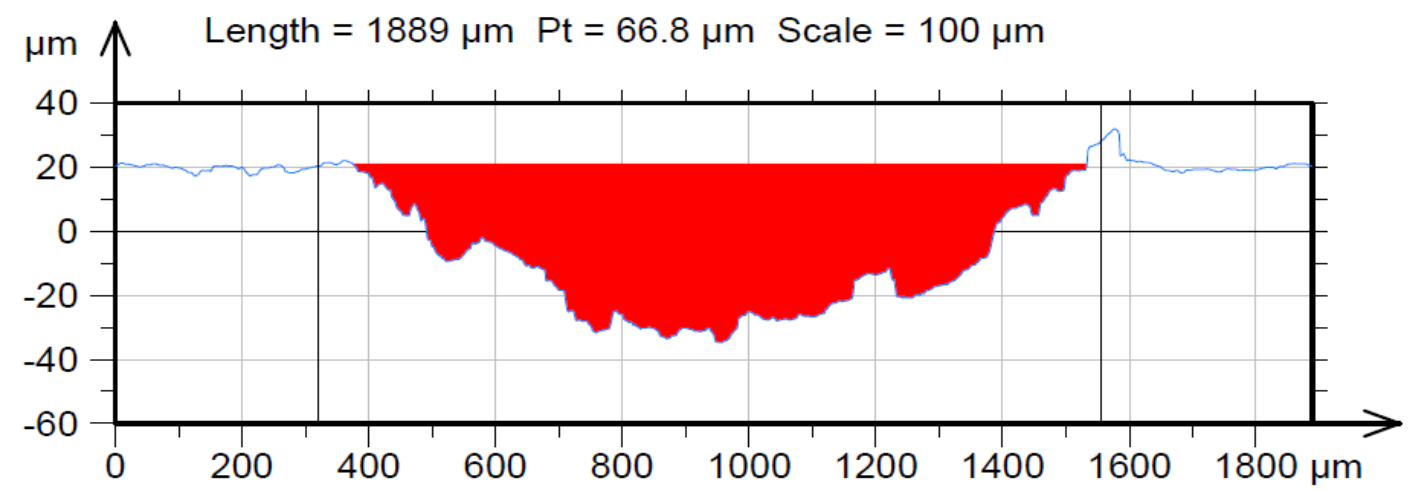

10. ábra. Jellemzö S235 minta kopási keresztmetszete

A kopási keresztmetszet néhány jellegzetességének elemzése, bemutatása után a számszerü értékelés adatait a 11. ábrán látható diagramon mutatjuk be. A diagram hasonló jellegü, mint a korábbiakban bemutatottak, azonban az eltérések egyes esetekben a korábban közölteknél nagyobb értéküek.

Az edzett daraboknál a sorrend a korábban bemutatottaknak megfelelöen megmaradt. Ezek szerint a körpályán jelölt edzett darabnál a legkisebb a kopási keresztmetszet átlaga (csökkenés 38 \%), és a szúrásmező is kisméretü, ennek megfelelően egy stabil folyamatról beszélhetünk. Az ES jelű sávosan hőkezelt mintáknál a csökkenés az alapanyaghoz képest 34 \% mértékű, valamint az átlag értékhez képest igen nagy szórással rendelkezik. Ebből levonhatjuk azt a következtetést, miszerint a mért adatok a folyamat instabilitására utalnak. 
A bevonatolt daraboknál a S235-ös acéllemezhez képesti kopási keresztmetszet csökkenése 36 \% mértékü (közepes) a szórás tartománya itt is magasnak tekinthető.. A legkisebb kopási keresztmetszet értékeket is a $\mathrm{P}$ jelü mintáknál mértük megegyező terhelési körülmények fennállása esetén. Az itt számítható százalékos eltérésen azért nem jelenik meg ez az érték, mert a vizsgált S235-ös lemez kopással szembeni ellenálló képessége nagyobb, mint a C45-ös alapanyag hasonló jellemzője.

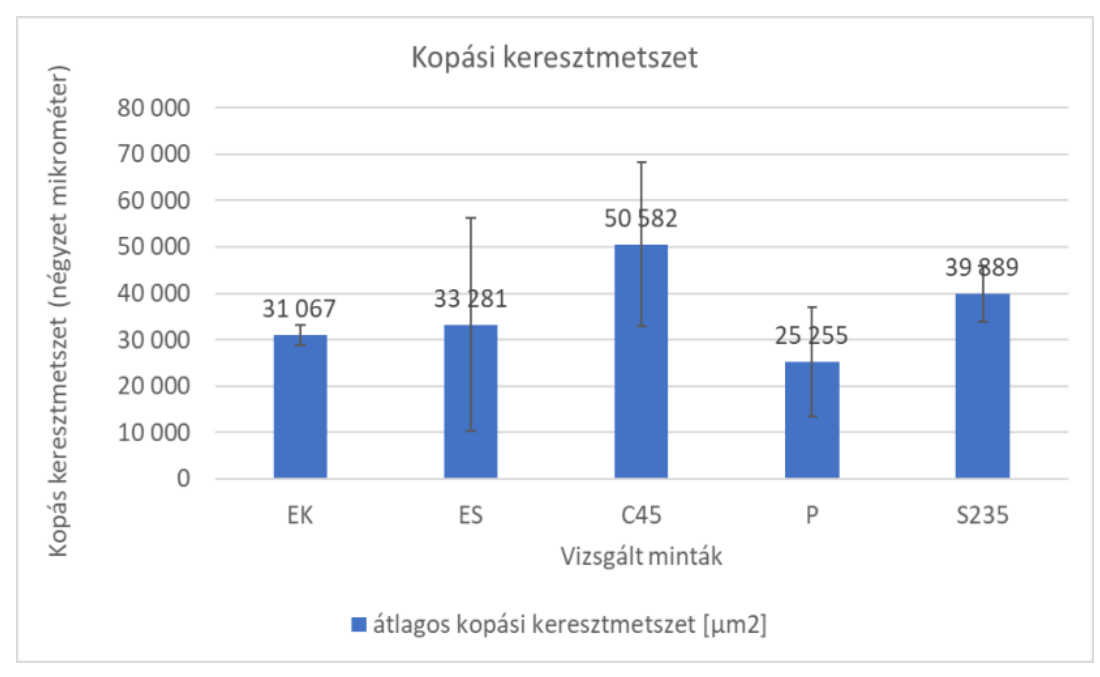

11. ábra. A kopási keresztmetszet értéke a különbözö jelü mintáknál

A kopás mértékét az összehasonlító vizsgálataink során a kopási keresztmetszet mellet jól mutatja a lekopott anyag tömegének mértékei is. Az eredményeket a 12. ábrán mutatjuk be. A kopás tömegében a sorrend hasonló, a korábbiakban olvasottakhoz.

Az edzett daraboknál a kör mentén edzett mintánál a legkisebb a csökkenés mértéke: 36 \%. Az ES mintákon a csökkenés ennél valamivel kisebb mértékü, összesen $30 \%$.

A bevonatolt darabon az S235-ös mintához képesti csökkenés mértéke $31 \%$. Az edzett és a bevonatolt darabok kopási tömegeinek összehasonlításánál a jövőbeni vizsgálatoknál szükséges figyelembe venni a lekopott anyagok sürüségének eltéréseit is. 


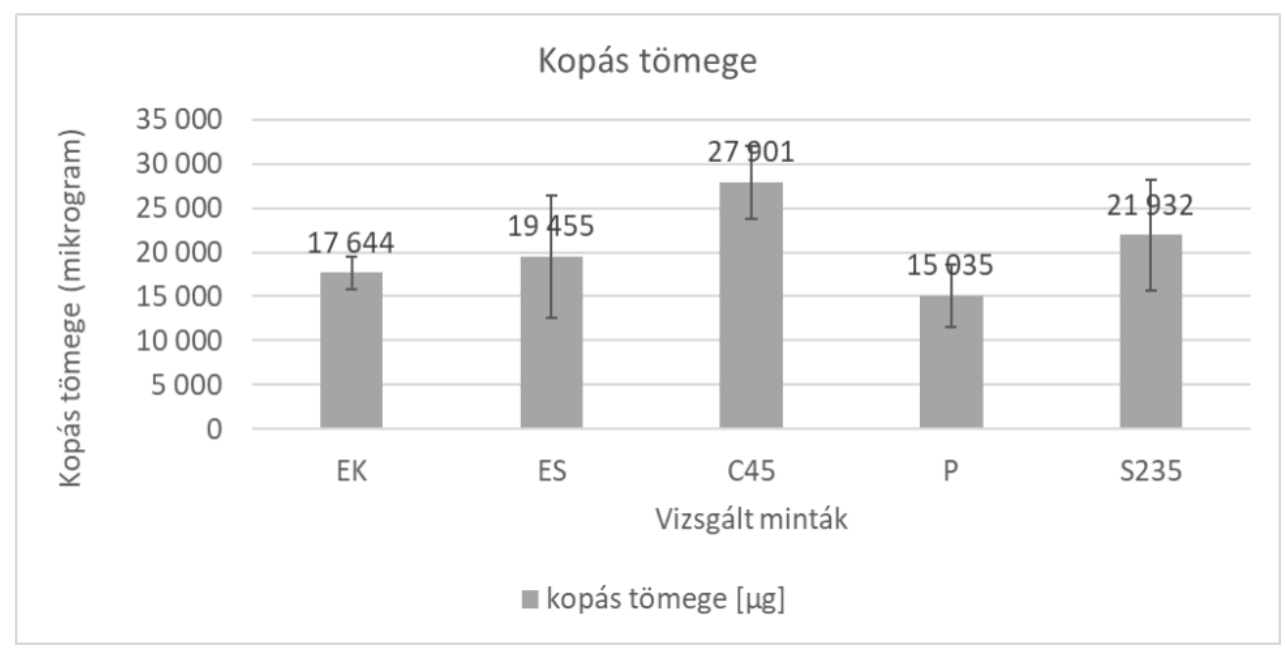

12. ábra. A kopási tömeg értéke a különbözö jelü mintáknál

A kopási tulajdonságok közül a súrlódási együttható értéke és folyamat közbeni alakulása is fontos jellemző. A súrlódási együttható a felületi normális erő és a súrlódási erő vizsgálat közbeni mérésével, és a hányadosuk képzésével határozható meg. A 13. ábrán a súrlódási együtthatók (COF) átlagának értéke - több mintán és időben kiátlagolva - látható,. A diagramon megfigyelhető, hogy a legnagyobb COF értéket a körpályán edzett daraboknál mértük. Mértékes a sávosan edzett darabok esetén volt a legkisebb a C45-ös alapú minták közül. A C45 kezeletlen alapanyagnál mért értékek a szélsőértékek között helyezkedtek el.. Az ES mintáknál a szórások kimagaslóan nagy értékeket mutattak.

A bevonatolt mintáknál a COF értéke hasonlóan magas volt, mint az EK mintáknál, az S235ös alapanyag viszont itt mutatta a legkisebb COF értéket. A nagyobb súrlódási együttható nagyobb kopást is eredményezhetett volna, ugyanakkor a korábban bemutatott kopási keresztmetszet és kopási tömeg diagramokon nem ezt láttuk. Mindezekből az a következtetés is levonható, hogy nagyobb súrlódási együttható mellet is kisebb kopási értékek mérhetők a felületkezet minták esetében.

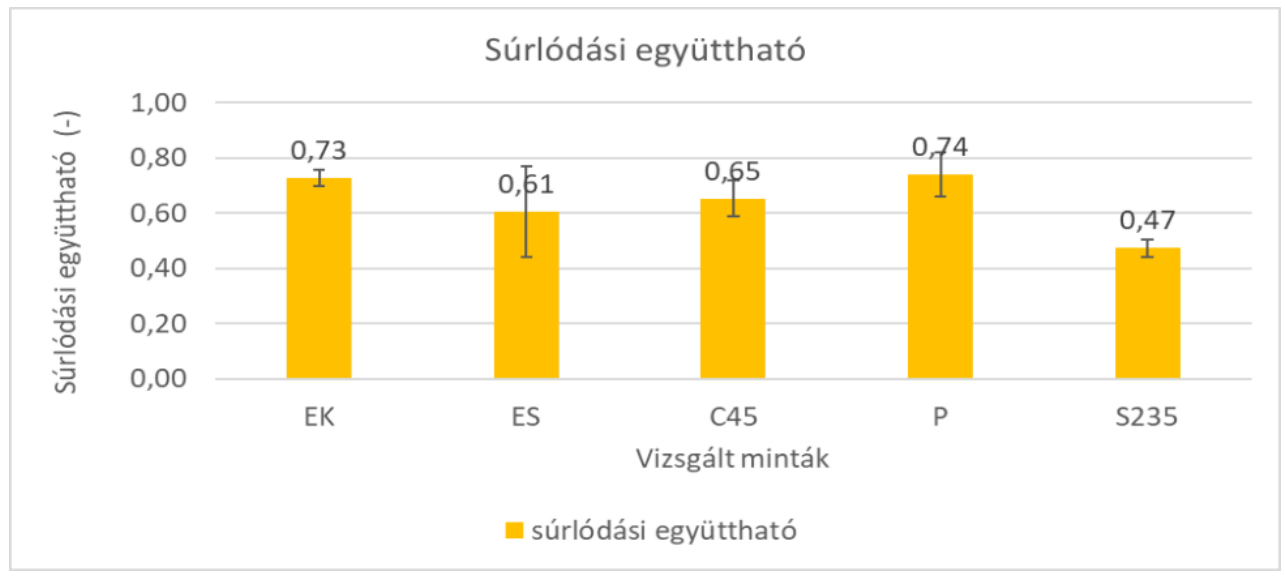




\section{3. ábra. A súrlódási együttható értéke különbözö koptatási mintáknál}

A lézeresen edzett darabok szerkezeti vizsgálatának és a kopási tulajdonságok eredményeinek bemutatása és elemzése alapján bemutattuk, hogy a hökezelt sáv felületen mért oldalirányú keménységeloszlásának csökkenése a felületi kopással szembeni ellenállást is befolyásolja.

Az anyagvizsgálatok során kimért keménység változási adatok - amelyek az egyes sávokon belüli keménység eloszlásából és nagyobb felületeknél az átlapolódáskor bekövetkező kilágyulás eredményeként jönnek létre - arra szolgának bizonyítékul, hogy a keménység változás a kopási jellemzők mértékére is hatással van. Ezt megfigyeltük az edzett darabok kopási nyomain, amely beigazolta korábban megfogalmazott feltevéseinket.

A kísérletek során a rendelkezésre álló lézerfejjel sávonként volt lehetőségünk nagyobb felületek edzésére. Az ideális megoldás egy rezgőtükörrel ellátott szkenner optika lenne, amely vonali fókusz mozgatásával a teljes kívánt szélességben alkalmas lehetne a felület homogén keményítésére.

A felületkezelés és az alapanyagok közötti keménységi és a lekoptatott anyag tömeg arányait a edzés esetére a 14., bevonatolás esetére a 15 . ábrán mutatjuk be, ahol az alapanyag keménységi és kopási tömeg értékeit vettük $100 \%$-nak.

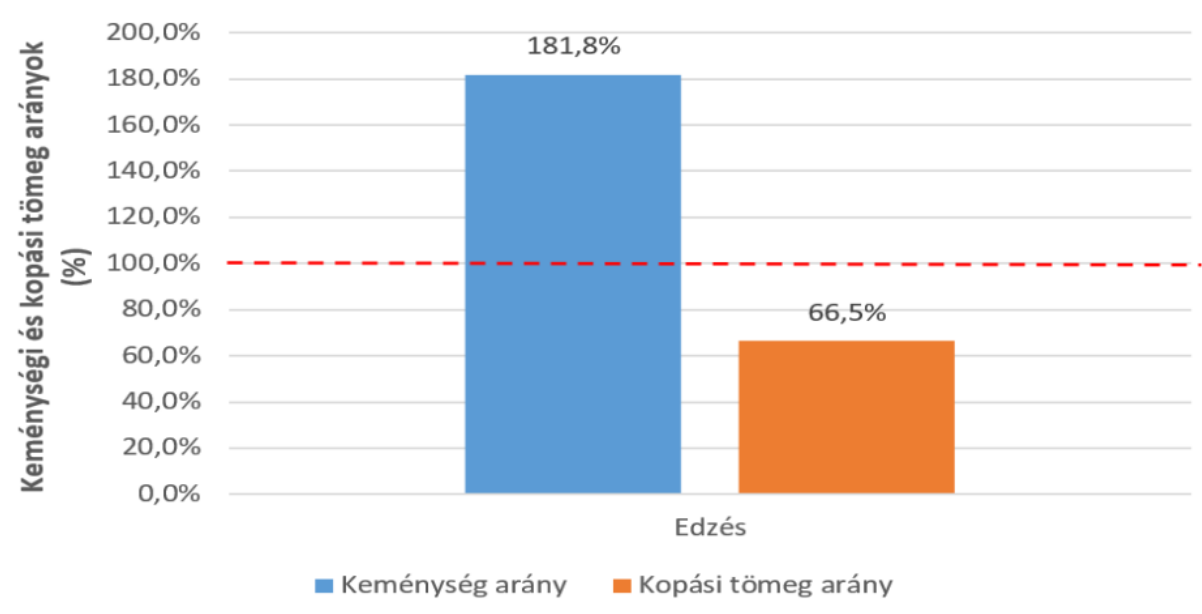

14. ábra. Az anyagszerkezeti és kopási tulajdonságok összehasonlítása edzésnél 


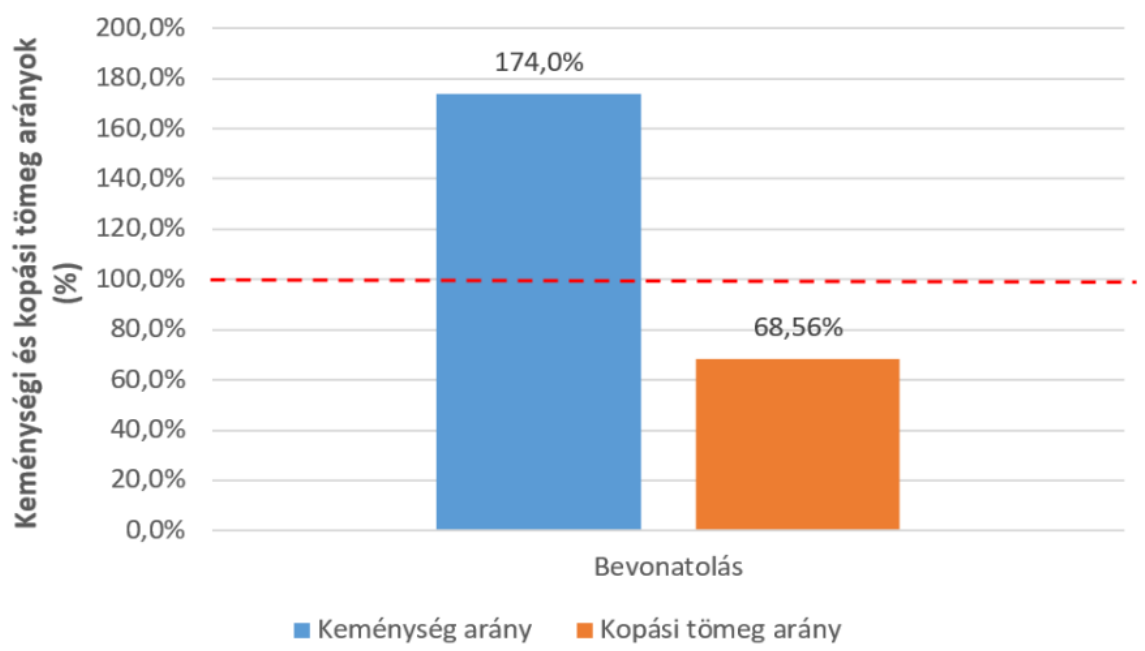

15. ábra. Az anyagszerkezeti és kopási tulajdonságok összehasonlítása bevonatolásnál

\section{4. ÖSSZEFOGLALÁS}

A vizsgálataink eredményeképpen megállapítható, hogy a lézersugárral felületkezelt mintáknak a kopással szembeni ellenállása jobb, mint a kiválasztott alapanyagoké.

Megállapítható, hogy a kilágyulást is figyelembe véve az edzett felület átlagosan $80 \%$-kal nagyobb keménysége 33 \%-kal csökkentette a kopási tömeg mértékét, amely egyenletes edzési technika megvalósítása esetén tovább növelhető.

A bevonatolásnál a kiválasztott minta felületi keménységében a tárcsa felületén nem volt olyan jellegű keménység változás, mint az edzett darabok esetében, ezért a kopási tulajdonságai is egyenletesebbek az edzett mintákhoz viszonyítva.

A kopásnyomok szélességében nem mértünk jelentős eltérés. A beolvadási mélység csökkentésével a felkeveredés mértéke is csökkenthetö, így a bevonati keménység mértéke növekedhet.

Ezzel az eljárással a kopási tulajdonságok még tovább javíthatók. A megvizsgált paraméterek mellett az átlagosan 74 \%-kal keményebb bevonat ugyanazon az S235-ös alapanyagon 32 \%os kopási tömeg csökkenést eredményezett, amely összességében a kopással szembeni ellenállást javította. 


\section{Felhasznált irodalom}

[1] W. M. Steen: Laser Surface Cladding, Surface and Coating Technology, 1990, p. 369-387

[2] PengfeiFan: Study on process optimization of WC-Co50 cermet composite coating by laser cladding, International Journal of Refractory Metals and Hard Materials, Volume 87, February 2020, 105133

[3] W. Tarasiuk, A.I. Gordienko, A.T. Wolocko, J. Piwnik, B. Szczucka-Lasota: The tribological properties of laser hardened steel 42CrMo4, Archives of Metallurgy and Materials, Volume 60, Issue 4, 2015

[4] M. Pellizzari, M.G. De Flora: Influence of laser hardening on the tribological properties of forged steel for hot rolls, Wear 271 (2011) 2402- 2411

\section{Köszönetnyílvánítás}

A dokumentumban bemutatott kutatás eredményeinek elérésében köszönetet mondunk az EDUTUS Egyetem Lézer Laboratóriumának dolgozóinak: Molnár Istvánnak és Suta Máténak, illetve Fodor Péter BME hallgatónak a vizsgálatok végrehajtásában történt részvételéért.

A projekt a Nemzeti Kutatási és Innovációs Hivatal támogatásával, az NKIH Alapból támogatott, EFOP-3.6.1-16-2016-00009 azonosítószámú pályázathoz kapcsolódóan valósult meg. A szerzők köszönik a támogatást. 